\title{
Sektor kultury w Polsce - ujęcie lokalne
}

\author{
Stella Kaczmarek ${ }^{\star}$
}

\begin{abstract}
Streszczenie: Sektor kultury, mimo że nie jest największym sektorem działalności gospodarczej, ma duży wpływ na rozwój ekonomiczny i gospodarczy kraju. Zarówno państwo, jako główny mecenat kultury, jak i sektor prywatny wraz z sektorem non-profit wspierają tak działalność sektora kultury, jak i sektora przemysłów kreatywnych. W niniejszym artykule podjęte zostaną tematy dotyczące rozwoju sektora kultury w Polsce, jego głównych zadań i problemów, elementów polityki kulturalnej państwa polskiego oraz problemy globalizacji kultury. Dodatkowo omówione zostaną takie aspekty, jak: rola, cele i formy finansowania sektora kultury w Polsce, analiza aktualnej sytuacji artystów i twórców na polskim rynku, struktura zatrudnienia w sektorze kultury oraz problemy i zagrożenia dla działalności kulturalnej w Polsce.
\end{abstract}

Słowa kluczowe: sektor kultury, polityka kulturalna, artyści, zatrudnienie, globalizacja.

\section{Sektor kultury - informacje ogólne}

Pojęcie „sektora kultury” bardzo się już upowszechniło, używa się go od ujęcia możliwie najszerszego kontekstu (zbiór wszelkich możliwych podmiotów kultury - instytucji kultury, szkół artystycznych, organizacji pozarządowych, przedsiębiorstw prywatnych) po zawężone kryteria (np. zbiór podmiotów reprezentujących przemysły kultury czy przemysły kreatywne) ${ }^{1}$. Słowo „sektor” podobnie jak „branża” odwołuje się do pojęć gospodarki (economy) i przemysłu (industry). Mówiąc i wspominając o sektorze kultury, najczęściej mamy na myśli:

- rynek pracy dla kadr kultury, artystów (nowe miejsca pracy);

- obszar kultury związany z gospodarką (neoindustrializacja, rozwój gospodarki wiedzy);

* Akademia Muzyczna im. Grażyny i Kiejstuta Bacewiczów w Łodzi, Wydział Kompozycji, Teorii Muzyki, Dyrygentury, Rytmiki i Edukacji Muzycznej.

1 Sektor kultury w Polsce, http://badania-w-kulturze.mik.krakow.pl/2012/02/22/sektor-kulturyujecie-instytucjonalne-i-znaczenie-gospodarcze/ [dostęp 10.04.2018]. 
- kluczowy obszar wzrostu innowacyjności i kreatywności (badania i rozwój);

- rynek usług związanych z czasem wolnym, rozrywką, turystyką;

- potencjał rozwoju metropolitarnego i regionalnego (nowoczesne miasto, zrównoważony rozwój, wysoka jakość życia)².

Sektor kultury jest pożądaną i ważną, choć ciągle niedofinansowaną branżą w gospodarce. Sektor kultury jest też ekspansywny i obejmuje coraz to nowe obszary związane z „kulturą", np. Internet, technologie multimedialne, turystykę, rozrywkę. Im więcej sektora kultury w danej gospodarce, tym lepiej świadczy to o jej poziomie rozwoju, kreatywności, innowacyjności, szansach na przyszłość. Stąd sektor kultury (i związane z nim pojęcia, takie jak: kreatywność, przemysły kultury, własność intelektualna, rozwój w oparciu o zasoby kultury) dominuje w obecnej debacie na temat kultury.

Sektor kultury to realnie funkcjonujący obszar działań wielu podmiotów i aktorów kultury. Działania te mają znaczenie gospodarcze (nie zawsze innowacyjne i kreatywne), choć tylko część podmiotów można uznać za przedsiębiorstwa generujące dochody, współtworzące gospodarkę 3 . Pozostałe mają ogromne znaczenie $\mathrm{w}$ obrocie gospodarczym, uczestnicząc $\mathrm{w}$ redystrybucji dóbr i zapewniając usługi publiczne w zakresie kultury: tworząc system wsparcia dla rozwoju biznesu i przedsiębiorczości, finansując rozwój sektora kultury czy też kreując polityki rozwoju sektora kultury. Można zatem mówić o pewnym „ekosystemie kulturalnym”, w którym rozwija się gospodarka korzystająca z zasobów kultury.

\section{Polityka kulturalna państwa}

Państwo - czyli sektor publiczny - wspiera sztukę, ponieważ wychodzi z założenia, że przynosi ona społeczne korzyści. Ekonomika polityki kulturalnej państwa objawia się poprzez wspieranie działalności kulturalnej (sztuki, dziedzictwa kulturowego, działalności wydawniczej, produkcji filmów, telewizji publicznej) poprzez wykorzystanie takich instrumentów, jak: dotacje, zachęty inwestycyjne, ulgi podatkowe, specjalne regulacje, edukacja, szkolenia itd. ${ }^{4}$

Od czasów II wojny światowej w wielu krajach związek pomiędzy kulturą a państwem zacieśnił się poprzez tworzenie polityki kulturalnej. Jest to mechanizm gwarantujący państwu wpływ na dziedzinę kultury. Ustalenie aspektów kształtowania polityki kulturalnej poszczególnych państw miało miejsce podczas konfe-

\footnotetext{
Ibidem.

Ibidem.

4 D. Throsby, Ekonomia i kultura, Warszawa 2010, s. 124.
} 
rencji Światowej Komisji ds. Kultury i Rozwoju (WCCD) w Sztokholmie w roku 1998. Owocem ustaleń było pięć zadań polityki kulturalnej $j^{5}$, tj.:

1. Polityka kulturalna ma być jednym z kluczowych elementów strategii rozwoju.

2. Promowanie kreatywności i partycypacji w życiu kulturalnym.

3. Wspieranie przemysłów kultury oraz dziedzictwa kulturowego poszczególnych państw.

4. Promowanie różnorodności kulturowej i językowej w ramach społeczeństwa informacyjnego.

5. Przeznaczenie większej ilości zasobów finansowych i ludzkich na rozwój kultury.

W punktach tych widać silną relację pomiędzy polityką kulturalną a polityką gospodarczą. Polityka kulturalna bowiem powinna brać pod uwagę wartości ekonomiczne i kulturowe swojej działalności (wartość i ważność celów), czyli dążyć do maksymalizacji wartości ekonomicznej i kulturowej. Istnieją jednak sytuacje, kiedy powinno się rozróżnić te dwa aspekty. Znaczenie ekonomiczne będzie miało większe znaczenie we wspieraniu przemysłów kultury (czyli produkcji towarów i usług kulturalnych), natomiast znaczenie kulturowe we wspieraniu artystów, np. sztuk kreatywnych i koncentrowaniu się na aspekcie twórczej ich działalności. Ogólnym zadaniem współczesnej polityki kulturalnej jest zatem takie stymulowanie przemysłu kultury, aby miał on jak największy wkład w gospodarkę.

Kultura stanowi kontekst działalności gospodarczej i może wpływać na wyniki gospodarcze. W fundamentalnym sensie kultura leży u podstaw procesu rozwoju i wpływa na zachowania gospodarcze - zwłaszcza w krajach rozwijających się. Wpływ kultury na działania gospodarcze danego kraju może przejawiać się poprzez fakty, $\mathrm{iz}$ :

1) kultura może wpływać na wydajność gospodarczą;

2) kultura może wpływać na poziom sprawiedliwości;

3) kultura może mieć wpływ na cele gospodarcze i społeczne, które stawia sobie społeczeństwo/dana grupa.

Przełomowym momentem dla rozwoju polityki kulturalnej w czasach powojennych na zachodzie, a w latach 80 . w Polsce, było dopuszczenie sektora prywatnego do finansowania kultury. Co prawda państwo jest cały czas odpowiedzialne za prowadzenie polityki kulturalnej, lecz jego władza jest ograniczona poprzez np. redukcję nakładów budżetowych, wycofanie się państwa z wielu obszarów działalności twórczej. W chwili obecnej także komercyjni sponsorzy i prywatni mecenasi wyznaczają kierunki rozwoju kultury. Tę tendencję nazywamy „prywatyzacją i liberalizacją rynkową" sektora kultury

5 Ibidem, s. 128-129.

6 Ibidem, s. 65-66.

7 Ibidem, s. 130. 


\section{Kultura jako nowa gospodarka}

Kultura ma ogromy wpływ na rozwój społeczny i gospodarczy kraju, ponieważ kultura i ekonomia wzajemnie się uzupełniają. Źródłem finansowania kultury jest zawsze gospodarka, a aktywność kulturalna jest uwarunkowana ekonomicznie ${ }^{8}$. Kultura jest także środkiem do osiągania gospodarczych celów ekonomicznych i ogólnej wydajności gospodarczej. Z drugiej strony działalność gospodarcza jest silnie uwarunkowana kulturowo. W ocenie wartości dóbr i usług kulturalnych powinno się uwzględniać zarówno jej wartość kulturową, jak i ekonomicznąa. Istnieje zarówno materialny rynek dzieł sztuki, jak i analogiczny (niematerialny) rynek idei stanowiących konieczny atrybut wytworu tych dzieł. Rynek materialny określa ekonomiczna wartość dzieła, natomiast rynek idei determinuje jego wartość kulturową. Dzieło artystyczne tym samym funkcjonuje na tych dwóch rynkach równocześnie.

Wartość kultury zauważył nawet Bank Światowy, który ogłosił, że kultura pomaga osiągnąć takie cele rozwojowe poszczególnych państw, jak ${ }^{10}$ :

- stwarzanie nowych możliwości generowania dochodów, np. za sprawą produkcji kulturowej;

- wspomaganie lokalnego rozwoju dzięki zasobom społecznym, kulturowym, fizycznym i gospodarczym;

- generowanie dochodów z istniejących aktywów [kulturowych] poprzez rewitalizację, turystykę oraz ochronę aktywów naturalnych;

- wspomaganie kapitału społecznego i potencjału dynamicznych społeczności;

- rozszerzanie strategii rozwoju ludzkiego;

- budowanie potencjału w dynamicznych społeczeństwach, opartych na wiedzy.

Bank światowy - chcąc realizować te cele - podejmuje wysiłki, aby „uwzględnić zagadnienia kulturowe $\mathrm{w}$ strategiach kredytowych we wszystkich sektorach oraz promować kulturę w oddolnych ruchach budowania społeczności” ${ }^{11}$.

Kultura uznana została za nowy obszar korzystnego inwestowania i tworzenia miejsc pracy, źródło kreatywności oraz innowacyjności ${ }^{12}$. Zdaniem Jerzego Hausnera $^{13}$ kultura stanie się podstawowym zasobem, „nową gospodarką, nowym mechanizmem rozwojowym, i co za tym idzie, potrzebna będzie zmiana myślenia o kulturze. Aby za trzydzieści lat móc konkurować na rynku w sensie ekonomicz-

8 J. Hausner, A. Karwińska, J. Purchla, Kultura a rozwój, Warszawa 2013, s. 14.

9 D. Throsby, Ekonomia i kultura, s. 49.

10 Ibidem, s. 72-73.

11 Ibidem, s. 73.

12 T. Dudzik, D. Ilczuk, SOSART. Badanie rynku pracy artystów i twórców w Polsce, „Zarządzanie Kulturą" 2013, t. 6, nr 3, s. 10.

13 J. Hausner, Gospodarka stanie się kulturq, [w:] R. Pawłowski (red.), Bitwa o kulturę. \#przyszłość, Warszawa 2015, s. 76. 
nym, potrzebna będzie gospodarka oparta w dużo większej mierze na kulturze. Pozwoli to na wytwarzanie bardziej złożonych, innowacyjnych technologii i dóbr.

Kultura nie powinna być rozumiana tylko i wyłącznie w odniesieniu do działalności rynkowej, ale mieć swoją wolność, niezależność i autonomię. Trzeba podkreślić, iż część kultury powinna być wyłączona z procesów ekonomizacji, komercjalizacji i instrumentalizacji. Jest to proces potrzebny do rozwoju społeczeństwa świadomego swoich potrzeb. W przyszłości chodzi przede wszystkim o to, aby gospodarkę uczynić kulturą, ponieważ kultura posiada nie mniejszy potencjał rozwojowy niż rynek. Rozwój kultury służy zatem rozwojowi działalności biznesowej.

\section{Kultura w czasach globalizacji}

Nowym zagrożeniem dla kultur jednonarodowościowych, silnie zdecentralizowanych jest globalizacja, która kruszy wał ochrony niezależności kulturowej poszczególnych państw oraz upowszechnia wartości masowej kultury popularnej ${ }^{14}$. Postęp globalizacji stanowi punkt zwrotny w polityce kulturalnej końca XX w. Zdaniem Davida Throsby’ego „rosnąca mobilność kapitału, rewolucja komunikacyjna, coraz większa współzależność gospodarek narodowych w ramach globalnej struktury rynkowej miały znaczące konsekwencje dla kultury"15.

Przed nadejściem globalizacji ludzki świat zbudowany był z izolowanych kulturowych wysp, które dziś, czyli w epoce globalizacji, albo łączą się ze sobą, albo upodabniają się do siebie, albo tylko manifestują swoje istnienie ${ }^{16}$. Wiele narodów związanych z unią wnosi o uznanie „pluralizmu kulturowego”, czyli „multikulturalizmu”. Ta wielokulturowość - czyli współwystępowanie na tej samej przestrzeni dwóch lub więcej grup społecznych o odmiennych kulturowo cechach ${ }^{17}$ - jest znaczeniem wyjętym prosto z kanonu politycznej poprawności, która ma być pielęgnowana, kultywowana, podtrzymywana i finansowana. Uznania wielokulturowości nie należy jednak mylić z doktryną tolerancji i szacunku dla inności.

Zarządzanie kulturą w niedalekiej, chaotycznie zapowiadającej się przyszłości będzie więc polegało na zarządzaniu "mozaiką diaspor”18 (zbiorowisku nakładających się na siebie i krzyżujących ze sobą etnicznych archipelagów) oraz poczyna-

14 A. Karwińska, Kultura, [w:] J. Hausner, A. Karwińska, J. Purchla (red.), Kultura a rozwój, Warszawa 2013, s. 67.

15 D. Throsby, Ekonomia i kultura, s. 131.

16 Por. M. Golka, Socjologia kultury, Warszawa 2013, s. 262.

17 Ibidem.

18 Z. Bauman, Kultura w płynnej nowoczesności, Narodowy Instytut Wizualny, Warszawa 2011, s. 95. 
niach i inicjatywach jednostkowych. Jak wspomina Jeffrey Weeks, „Najsilniejsze poczucie wspólnoty zrodzić się może w grupach, które dochodzą do wniosku, że przesłanki ich zbiorowego istnienia są zagrożone i które budują na tym odkryciu wspólnotę tożsamości, która dostarcza im poczucia mocy” ${ }^{19}$. Musimy się pogodzić z tym, iż różnokulturowość, wielokulturowość i transkulturowość staną się „immanentnym składnikiem współczesnego życia społecznego”, ponieważ procesy globalizacji zwiększają wielokulturowość świata oraz wymuszają na nas ich akceptację i umiejętność harmonijnego funkcjonowania obok nas ${ }^{20}$.

Wspieranie, promowanie i dotowanie mobilności artystów ma na celu m.in. wspieranie dialogu międzykulturowego, tak ważnego w czasach globalizacji. Zagraniczna mobilność artystów opiera się na eksporcie twórczości, nawiązywaniu kontaktów międzynarodowych, udziale w stażach zagranicznych, programach wymiany, tournée czy też rezydencjach ${ }^{21}$. Konwencja UNESCO z roku 2005, zawarte tam Zasady Solidarności i Współpracy Międzynarodowej oraz zbiór wytycznych dotyczących mobilności artystów wydanych w roku 2011 przez Komisję Europejską dbają o zacieśnianie współpracy sektorów kultury państw europejskich. Przykładem interesującego rozwiązania w tej kwestii jest Krajowa Rada Mobilności i Różnorodności w Sztuce stworzona w Finlandii, Artists' International Development Fund w Wielkiej Brytanii (finansująca rozwój współpracy międzynarodowej artystów i pracowników kreatywnych) czy też polski Instytut Adama Mickiewicza (IAM) w Polsce.

\section{Rola, cele i nowoczesne formy finansowania sektora kultury w Polsce}

Sektor kultury w ostatnich dwudziestu latach rozwijał się bardzo dynamicznie. Mimo że polityka kulturalna przeważnie związana jest ze zmianami polityczno-gospodarczymi, po roku 2000 znacznie zwiększyła się liczba instytucji kultury o statusie instytucji narodowych. Zmieniło się także rozumienie kultury i obecnie traktuje się ją jako „długoterminową inwestycję ekonomiczną”, mającą wpływ na rozwój kraju 22 .

19 J. Weeks, 1989, cyt. za: Z. Bauman, Kultura w płynnej nowoczesności, s. 101.

20 M. Golka, Socjologia kultury, s. 264.

21 D. Ilczuk, Wsparcie dla artystów i twórców. Perspektywa międzynarodowa, Warszawa 2017, S. 125.

22 A. Wąsowska-Pawlik, Polityka kulturalna Polski 1989-2012, [w:] J. Hausner, A. Karwińska, J. Purchla (red.), Kultura a rozwój, Warszawa 2013, s. 120-121. 
„W latach 90. transformacja gospodarki $\mathrm{z}$ centralnie planowanej w rynkową, wymusiły serię działań adaptacyjnych ze strony sektora kultury"23. Musiała nastąpić przemiana świadomości ludzi kultury, zmiana sposobu ich myślenia związana np. z nauką planowania perspektywicznego. Polski system finansowania kultury opiera się na sektorze publicznym (jako głównym mecenatem) i uzupełniającej roli sektora prywatnego. Ostatnie dwadzieścia lat przyniosło w Polsce niezwykły rozwój tzw. sektora pozarządowego, czyli pojawienie się nowych, pozabudżetowych źródeł finansowania, a także dynamiczny wzrost liczby podmiotów zaliczanych do trzeciego sektora, zwłaszcza fundacji i stowarzyszeń24 ${ }^{4}$. Trzeci sektor (non-profit) wykorzystuje środki finansowe pochodzące z różnych źródeł, np. z funduszy unijnych.

Sektor kultury - zdaniem A. Wąsowskiej-Pawlik ${ }^{25}$ - współtworzą obecnie instytucje finansowane ze środków publicznych, organizacje non-profit i należące do przemysłu kultury/przemysłów kreatywnych. Działalność kulturalna może być aktualnie prowadzona $\mathrm{w}$ trzech sektorach gospodarki: publicznym, rynkowym (prywatnym) i non-profit ${ }^{26}$. Ekonomiczny wymiar sektora kultury doprowadził przez ostatnie 20 lat do stworzenia „przemysłu kultury”, czyli takiej działalności kulturalnej, która z jednej strony posiada cechy twórczości, a z drugiej skierowana jest na osiąganie zysku i działa według zasad rynkowych. $Z$ drugiej jednak strony - zdaniem D. Ilczuk - „kultura to jedyny niezreformowany sektor gospodarki w Polsce"27.

Państwowy mecenat sztuki i polityczne instancje zawiadujące i zarządzające kulturą pośredniczyły w doprowadzaniu dzieł sztuki do odbiorców. Na przestrzeni ostatnich trzydziestu lat w Polsce (a w Europie zdecydowanie wcześniej) pojawiły się nowe instytucje - na miejsce pozostawionych przez pełnomocników władz państwowych - czyli agencje pracy, agencje eventowe, menedżerowie kultury, prywatni mecenasi i przedsiębiorcy związani z rynkiem sztuki. W obecnych czasach niestety te instytucje pośredniczące nie posiadają ugruntowanej pozycji ze względu na niski poziom profesjonalizacji ich rynku pracy. Artyści i twórcy chcieliby znajdować się pod opieką profesjonalnej opieki menedżerskiej (indywidualnej bądź w agencjach artystycznych), lecz nie czynią tego ze względu na wysokie koszty, brak zaufania oraz brak odpowiednio przeszkolonych kandydatów, posiadających odpowiednie umiejętności menedżerskie ${ }^{28}$.

23 D. Ilczuk, Reforma sektora kultury w Polsce, Warszawa 2017, s. 5.

24 Por. T. Staby, Rynek pracy w kulturze 1998-2002, Warszawa 2005, s. 5.

25 A. Wąsowska-Pawlik, Polityka kulturalna..., s. 121. Do przemysłów kultury zaliczamy m.in. przemyst audiowizualny, wydawniczy, fonograficzny, modowy, reklamowy itp.

26 T. Słaby, Rynek pracy w kulturze..., s. 6.

27 D. Ilczuk, Reforma sektora kultury..., s. 6.

28 D. Ilczuk, Rynek artystów i twórców w Polsce. Raport z badań, Bydgoszcz-Warszawa 2013, s. 17,105 i 223. 
Rynek sztuki stał się rynkiem konsumpcyjnym, nieuregulowanym, w którym największy wpływ na sytuację ma popyt. Wielkość popytu na rynku pracy artystów zależy - zdaniem D. Ilczuk - od gotowości do uczestnictwa w życiu kulturalnym (finansowania ze źródeł prywatnych obywateli) oraz stopnia zaangażowania państwa w finansowaniu „zbiorowej konsumpcji” dóbr kultury ${ }^{29}$. W przypadku sztuki na popyt wpływa np. upodobanie do danych produktów i usług artystycznych, a konsumpcja danych dzieł kulturalnych związana jest z poziomem wiedzy i rozumieniem tych przedstawień przez jej konsumentów ${ }^{30}$.

Głównym celem polityki kulturalnej państwa jest nie tylko oddziaływanie na stronę popytową rynku, ale także tworzenie nowych sposobów finansowania samych artystów oraz infrastruktury. Patronat państwa nad kulturą narodu uległ - podobnie jak wiele innych funkcji przez niego sprawujących - procesowi prywatyzacji, decentralizacji i deregulacji ${ }^{31}$.

Obecna polityka kulturalna w Polsce określana jest jako model posttransformacyjny - charakterystyczny dla krajów Europy Środkowej i Wschodniej. Jest to model oparty na zatrudnieniach etatowych w kulturze, dotacjach przeznaczanych od Państwa na działalność kulturalną oraz na grantach przyznawanych na poszczególne projekty z Ministerstwa. Państwo w większości ponosi odpowiedzialność za rozwój kultury i zachowanie dziedzictwa kulturowego. Z drugiej jednak strony podstawowym problemem jest decentralizacja i rewolucja cyfrowa. Model taki gwarantuje „względnie stabilne funkcjonowanie określonej liczby państwowych instytucji i programów jednocześnie delegując do samorządów większość obowiązków w zakresie wsparcia i finansowania kultury"32. Obecny model polityki kulturalnej w Polsce - mimo dużej absorbcji środków unijnych przeznaczonych na kulturę - nie zawiera „efektywnych mechanizmów wpisania kultury w strategię polskiej polityki rozwojowej" ${ }^{33}$.

Nowe tworzące się rynki kultury potrzebują małych, elastycznych i prężnych organizacji (podmiotów), które się do nich będą w stanie dostosować. Organizacje kulturalne skupiają się na wykrywaniu nowych tendencji w sztuce, realizowaniu artystycznych produkcji i na dystrybucji ich dóbr oraz zwiększeniu zainteresowania odbiorcy produktem wytworzonym z działalności kulturalnej.

29 Por. ibidem, s. 220.

30 D. Throsby, Ekonomia i kultura, s. 106.

31 J. Hausner, A. Karwińska, J. Purchla (red.), Kultura a rozwój, s. 50. Zob. także: A. Wąsowska-Pawlik, op. cit., s. 115.

32 Por. D. Ilczuk, Reforma sektora kultury..., s. 6.

33 Ibidem, s. 8. 


\section{Zatrudnienie w sektorze kultury w Polsce}

W porównaniu $\mathrm{z}$ innymi krajami europejskimi sektor kultury w Polsce jest słabiej rozwinięty. Odsetek osób pracujących w kulturze w Polsce był w roku 2015 jednym z niższych wśród krajów członkowskich UE. Sektor kultury stanowi - wg definicji ESS-net Culture - jeden z mniejszych sektorów polskiej gospodarki ${ }^{34}$.

W latach 1998-2002 w Polsce nastąpił nieznaczny wzrost zatrudnienia w sektorze kultury, do którego zaliczają się, według GUS, 22 grupy działalności zawodowej artystów (od działalności wydawniczej, po działalność rekreacyjną, rozrywkową, artystyczną i literacką, a kończąc na działalności bibliotek i archiwów). Proces urynkowienia w sektorze kultury w roku 2002 stanowił odpowiednio: 44\% sektor prywatny, $35 \%$ sektor publiczny i $21 \%$ trzeci sektor (non-profit). Świadczy to o zmianie charakteru finansowania kultury z instytucji subsydiowanych ze środków publicznych na instytucje poddawane regułom wolnego rynku. Liczba organizacji i firm zajmujących się kulturą wśród trzeciego sektora systematycznie się zwiększa i w roku 2010 wynosiła 14\% wszystkich organizacji tego typu (gdzie $32 \% \mathrm{z}$ nich prowadziło działalność sceniczną, teatralną, muzyczną albo kinematograficzną) $)^{35}$. Dodatkowo prawie $60 \%$ firm i podmiotów działających w kulturze powstało po roku 1989 - są to przeważnie małe firmy zatrudniające do 5 osób.

Wydatki publiczne na kulturę wyniosły ogółem w 2015 r. 2,01 mld euro (8,56 mld zł), co stanowiło $0,48 \%$ PKB oraz $1,15 \%$ łącznych wydatków publicznych państwa ${ }^{36}$. Inne źródło podaje, iż w roku 2015 wydatki publiczne na kulturę per capita wyniosły $0,48 \%$ PKB, a wydatki z budżetu państwa stanowiły $10 \%$ wydatków publicznych ogółem i 0,62\% całkowitego budżetu państwa polskiego ${ }^{37}$. Polska charakteryzuje się zatem wysokim poziomem decentralizacji w finansowaniu kultury. Samorządy dysponują bowiem około 80\% środków publicznych przeznaczanych na kulturę ogółem, na szczeblu państwowym wydawanych jest zaś około $20 \%$ tych funduszy ${ }^{38}$.

Analizując wydatki na kulturę w latach 2007-2017 w Polsce, okazuje się, że prawie połowa (48\%) wszystkich wydatków pochodzi z wydatków gospodarstw domowych. Z drugiej strony rośnie udział w wydatkach na kulturę jednostek samorządu terytorialnego (z 21 do 33\%) oraz udział wydatków na kulturę w wydatkach ogółem budżetu państwa ( z 5,8\% w roku 2007 do 8,1\% w roku 2017) ${ }^{39}$.

34 J. Baran, P. Lewandowski, Znaczenie gospodarcze sektora kultury w Polsce w latach 2008-2015, Warszawa 2017, s. 18.

35 Ibidem, s. 19-20.

36 S. Stano-Strzałkowska, Finansowanie kultury ze środków publicznych przykłady krajów europejskich, Warszawa 2017, http://konferencjakultury.pl/_admin/stuff/okk_finansowanie-_ kultury_1.pdf [dostęp 10.04.2018].

37 Por. D. Ilczuk, Reforma sektora kultury..., s. 6.

38 Raport Głównego Urzędu Statystycznego „Kultura w 2015 roku”, Warszawa, wrzesień 2016.

39 Por. D. Ilczuk, Reforma sektora kultury..., s. 30. 
Wydatki na kulturę poszczególnych gospodarstw domowych w Polsce osiągają wartość $4 \%$ ogółu ich wydatków w budżecie domowym. Jest to - zdaniem Doroty Ilczuk - jeden z najniższych wskaźników w Europie zachodniej, gdzie wydatki te przekraczają zwykle 10\% (w Niemczech jest to $11 \%)^{40}$.

Według Głównego Urzędu Statystycznego (GUS) w Polsce zatrudnienie w sektorze kultury (a dokładniej w podmiotach prowadzących działalność gospodarczą, zatrudniających powyżej 9 osób) wyniosło w roku 2002 1,8\% ogółu zatrudnionych, gdzie liczba pracujących w sektorze kultury stanowiła 1,2\% wszystkich pracujących ${ }^{41}$. Liczba podmiotów gospodarczych prowadzących działalność twórczą w roku 2010 wyniosła powyżej 26 tys. podmiotów gospodarczych.

Według Raportu Lewandowskiego i współpracowników z 2010 r. ${ }^{42}$ w sektorze kultury pracowało ok. 2,5\% ogółu pracujących (260 tys. zatrudnionych), a w przemysłach kreatywnych - 2,7\% (375 tys. zatrudnionych). W tej grupie najliczniej reprezentowana była sekcja działalności artystyczno-kulturalnej, w której pracowało 47\% osób ogólnie zatrudnionych w sektorze kultury. Co trzeci przedstawiciel zawodów artystycznych i twórczych zatrudniony był w zakładzie pracy zatrudniającym od 100 do 249 osób ${ }^{43}$.

W roku $2010 \mathrm{w}$ podmiotach gospodarczych o liczbie pracujących przekraczającej 9 osób zatrudnionych było 9,7 tys. „artystów i twórców”, z czego najliczniejszą grupę stanowili kompozytorzy, artyści muzycy i śpiewacy (ponad 5 tys.), drugą co do liczebności grupę stanowili aktorzy (1,9 tys.), trzecią zaś - artyści plastycy (około 1 tys.) ${ }^{44}$. $87 \%$ zatrudnionych artystów i twórców znajduje zatrudnienie w sektorze publicznym (60\% stanowią kompozytorzy, artyści muzycy i śpiewacy; $22 \%$ aktorzy, $8 \%$ choreografowie i tancerze). W sektorze prywatnym natomiast zatrudnienie znajdują artyści plastycy, reżyserzy i producenci, projektanci oraz prezenterzy radiowi i telewizyjni.

Struktura zatrudnienia w 2015 r. przedstawia się następująco: najwięcej osób, bo 75 tys. (czyli 1/4 całego zatrudnienia w kulturze) pracuje w branży: przedstawienia artystyczne, twórczość literacka i działalność obiektów kultury ${ }^{45}$. Działalność architektoniczna jest reprezentowana przez 37 tys. osób, a agencje reklamowe - które zajmują trzecią pozycję - przez 30 tys. osób. Zatrudnienie przekraczające 15 tys. osób jest widoczne w branżach, takich jak: wydawanie książek, telewizja, produkcja i dystrybucja filmów, biblioteki i archiwa oraz muzea ${ }^{46}$. Branże te sku-

40 Ibidem, s. 32.

41 Gtówny Urząd Statystyczny, http://stat.gov.pl/ [dostęp 12.01.2017].

42 P. Lewandowski, J. Mućk, Ł. Skrok, Znaczenie gospodarcze sektora kultury - wstęp do analizy problemu. Raport końcowy, Warszawa 2010.

43 Dane z publikacji GUS, Struktura wynagrodzeń wg zawodów w październiku 2010 roku, za: D. Ilczuk, Rynek pracy..., s. 326.

$44 \mathrm{Ibidem}$. Zob. także J. Baran, P. Lewandowski, Znaczenie gospodarcze sektora kultury w Polsce..., s. 18-20.

45 Ibidem, s. 19.

46 Ibidem. 
piają łącznie 4/5 zatrudnionych w sektorze kultury. Największa ekspansja zatrudnienia w ostatnich latach była widoczna m.in. w branżach: projektowanie specjalistyczne, biura architektoniczne, agencje reklamowe, fotografia oraz przedstawienia artystyczne i produkcja programów telewizyjnych ${ }^{47}$.

Sytuacja zatrudnienia w sektorze kultury do roku 2015 wzrosła w Polsce do 300 tys. osób, co stanowiło 1,9\% wszystkich pracujących w polskiej gospodarce ${ }^{48}$. Była to liczba porównywalna do liczby osób pracujących w hotelarstwie i gastronomii czy w górnictwie. Ogólnie od roku 2008, kiedy to w sektorze kultury pracowało 259 tys. osób, do roku 2015 oznacza to wzrost o 16\%. Sektor kultury stanowił $1,7 \%$ produktu krajowego brutto, lecz niestety udział kultury w wartości dodanej dla całej gospodarki spadł z 2,4\% w roku 2008 do $1,9 \%$ w roku $2017^{49}$. Wartość dodana sektora kultury w roku 2015 stanowiła ok. 22,7 mld zł, natomiast w sektorze przemysłów kreatywnych wynosiła 42,6 mld zł. Udział sektora kultury i przemysłów kreatywnych w PKB zmniejszył się zatem z 2,9\% PKB w 2008 roku do 2,4\% $\mathrm{w}$ roku $2015^{50}$.

Badania przeprowadzone przez Polską Radę Muzyczną ${ }^{51}$ w roku 2016 podają, iż prawie 30\% osób wykonujących zawód muzyka w Polsce pracuje w publicznych instytucjach kultury.

Dane z GUS odnoszące się do wykształcenia mówią, że ponad połowa (55\%) zatrudnionych w publicznym sektorze kultury to osoby z wyższym wykształceniem z przewagą kobiet $(64,4 \%)$, podczas gdy wśród zatrudnionych w sektorze prywatnym tylko co czwarty zatrudniony - przeważnie mężczyzna (60\%) - miał wyższe wykształcenie ${ }^{52}$. Wśród artystów i twórców udział kobiet w sektorze publicznym wynosi 45\%. Porównując Polskę do innych krajów europejskich, możemy stwierdzić, iż sytuacja zatrudnienia w podziale na płeć w sektorze kultury także posiada przewagę kobiet; wyższy był także procent zatrudnionych w sektorze kultury z wykształceniem wyższym w porównaniu do innych sektorów/obszarów gospodarki. Na przykład średnia różnica wynosi w krajach europejskich ca. 24\%, przy czym na Słowacji różnica ta wynosiła $34 \%$, a na Malcie jedynie $4 \%^{53}$.

Dodatkowym ważnym aspektem, związanym z działalnością kulturalną w Polsce jest zdecydowana „supremacja miasta stołecznego Warszawy”, gdzie skupionych jest ponad $1 / 4$ wszystkich zatrudnionych $\mathrm{w}$ tym segmencie rynku. Liczba pracujących w Warszawie stanowiła w roku 2002 ok. 12,8\% ogółu pracujących

47 Ibidem, s. 22.

48 Ibidem, s. 5 i 21.

49 Ibidem.

50 Ibidem, s. 37.

51 Badania Środowiska Muzycznego, PRM 2015-2016. Zob. także: D. Ilczuk, Wsparcie dla artystów i twórców, s. 103.

52 J. Baran, P. Lewandowski, Znaczenie gospodarcze sektora kultury w Polsce..., s. 25.

53 D. Ilczuk, Rynek pracy artystów i twórców w Polsce, s. 65. 
w Polsce i także tam (czyli w województwie mazowieckim) można było zaobserwować najwyższe wynagrodzenia w sektorze kultury ${ }^{54}$.

W latach 2008-2015 województwo mazowieckie nadal było miejscem skupiającym większość działalności kulturalnej w kraju oraz 1/3 zatrudnionych w kulturze ( 88 tys. osób, czyli $29 \%$ wszystkich osób pracujących w sektorze kultury). Udział wszystkich osób zatrudnionych/pracujących w sektorze kultury jest w tym województwie najwyższy i stanowi $3,2 \%{ }^{55}$. Udział województwa mazowieckiego w wartości dodanej polskiego sektora kultury wzrósł w ostatnich latach do 37\%. Oprócz Warszawy także inne duże ośrodki miejskie, tj.: Kraków, Gdańsk czy Wrocław, sprzyjają powstawaniu miejsc pracy związanych z działalnością kulturalną.

\section{Podsumowanie}

Wynagrodzenia artystów - w porównaniu do innych grup badanych - są bardzo niskie, a zarobki nieregularne. Sami artyści swoją sytuację ekonomiczną oceniają źle albo bardzo źle $(66 \%)^{56}$. W większości jest to wina - w opinii badanych artystów i twórców - obecnego systemu wspierania kultury (64\%), który promuje jedynie znanych i popularnych artystów. Kolejną przyczyną obecnego stanu rzeczy stanowią duże obciążenia podatkowe nałożone na artystów (23\%) oraz niski procent finansowania kultury z budżetu państwa $(7 \%)^{57}$. „Przeważnie zawody twórcy nie gwarantują przychodów na poziomie zapewniającym bezpieczeństwo socjalne, a praca pozaartystyczna stanowi przymus ekonomiczny"58.

Konieczność wspierania się dodatkowymi źródłami zarobkowania w Polsce wynika $\mathrm{z}$ faktu, iż ok. 30\% artystów posiada roczne przychody z pracy artystycznej poniżej 20 tys. PLN. Jedynie 2,5\% deklaruje przychody w wysokości 100 tys. PLN i dotyczy to jedynie wąskiego grona gwiazd z dziedziny muzycznej. W Polsce - w porównaniu z innymi krajami europejskimi - brakuje systemowych rozwiązań dotyczących pobudzania popytu na dobra kulturalne, właściwej polityki edukacyjnej oraz uregulowań prawno-finansowych dla artystów i twórców.

54 J. Baran, P. Lewandowski, Znaczenie gospodarcze sektora kultury..., s. 21-25.

55 Ibidem, s. 26.

56 Raport z badania oceniajacego model finansowania kultury w Polsce oraz wspierania twórców poprzez platformy crowdfundingowe, ZIPSSEE - Cyfrowa Polska, Warszawa 2017. Badanie w formie ankiety przeprowadzono na grupie 501 użytkowników serwisu Patronite.pl, a celem badania było zbadanie oceny użytkowników Internetu obecnego systemu finansowania pracy polskich twórców oraz użyteczności i korzyści płynących z wykorzystywania platform crowdfundingowych oraz serwisów z emecenatem, umożliwiających wspomaganie pracy konkretnych artystów lub konkretnych projektów artystycznych.

57 Ibidem, s. 3-4.

58 D. Ilczuk, Wsparcie dla artystów i twórców, s. 111. 
Aktualnymi problemami sektora kultury w Polsce są niskie płace, „grantoza” i „projektologia stosowana”, niemożność znalezienia stałego zatrudnienia, nieuregulowana współpraca artystów z publicznymi instytucjami kultury, brak ubezpieczeń społecznych oraz zgubny wpływ komercjalizacji na kulturę. „Nowoczesne państwo powinno stworzyć artystom podstawowe warunki do uprawiania sztuki i współpracy międzynarodowej. Kilkuprocentowy ułamek wydatków publicznych na kulturę nie wystarcza i potrzeba aktywnie poszukiwać nowych źródeł finansowania systemu kultury, zwłaszcza w sytuacji, w której polski sposób zarządzania kulturą powoli staje się odosobniony na tle zreformowanej Europy ${ }^{59}$.

\section{Bibliografia}

Badania Środowiska Muzycznego, Polska Rada Muzyczna 2015-2016.

Baran J., Lewandowski P., Znaczenie gospodarcze sektora kultury w Polsce w latach 2008-2015, Instytut Badań Strukturalnych, Warszawa 2017.

Bauman Z., Kultura w płynnej nowoczesności, Narodowy Instytut Wizualny, Warszawa 2011.

Borowiecki R. (red.), Perspektywy rozwoju sektora kultury w Polsce, Oficyna Ekonomiczna, Kraków 2005.

Dudzik T., Ilczuk D., SOSART. Badanie rynku pracy artystów i twórców w Polsce, „Zarządzanie Kulturą" 2013, t. 6, nr 3, s. 125-136.

ESSnet-Culture, ESSnet-Culture European Statistical Network on Culture, Final Report 2012.

Fatyga B. (red.), Raport o stanie kultury, Ministerstwo Kultury i Dziedzictwa Narodowego, Warszawa 2009.

Główny Urząd Statystyczny, http://stat.gov.pl/ [dostęp 12.01.2017].

Główny Urząd Statystyczny, Struktura wynagrodzeń wg zawodów w październiku 2010 roku.

Golka M., Socjologia kultury, wyd. 2, Wydawnictwo Naukowe Scholar, Warszawa 2013.

Hausner J., Gospodarka stanie się kultura, [w:] R. Pawłowski (red.), Bitwa o kulturę. \#przyszłość, Wydawnictwo Krytyki Politycznej, Warszawa 2015, s. 75-96.

Hausner J., Karwińska A., Purchla J. (red.), Kultura a rozwój, Narodowe Centrum Kultury, Warszawa 2013.

Ilczuk D., Reforma sektora kultury w Polsce, Centrum Badań nad Gospodarką Kreatywną, Uniwersytet SWPS, Warszawa 2017.

59 Por. D. Ilczuk, Reforma sektora kultury w Polsce, Warszawa 2017, s. 13. 
Ilczuk D., Wsparcie dla twórców i artystów. Perspektywa międzynarodowa, Uniwersytet SWPS, Warszawa 2017.

Ilczuk D. (red.), Rynek pracy artystów i twórców w Polsce. Raport z badań, Ministerstwo Kultury i Dziedzictwa Narodowego, Bydgoszcz-Warszawa 2013.

Karwińska A., Kultura, [w:] J. Hausner, A. Karwińska, J. Purchla (red.), Kultura a rozwój, Narodowe Centrum Kultury, Warszawa 2013, s. 57-80.

Lewandowski P., Mućk J., Skrok Ł., Znaczenie gospodarcze sektora kultury - wstęp do analizy problemu. Raport końcowy, Instytut Badań Strukturalnych, Warszawa 2010.

Pawłowski R. (red.), \#przyszłość. Bitwa o kulturę, Wydawnictwo Krytyki Politycznej, Warszawa 2015.

Raport $z$ badań oceniających model finansowania kultury $w$ Polsce oraz wspierania twórców poprzez platformy crowdfundingowe, ZIPSEE - Cyfrowa Polska, Warszawa 2017.

Raport Głównego Urzędu Statystycznego „Kultura w 2015 roku”, Warszawa 2016.

Sektor kultury w Polsce, http://badania-w-kulturze.mik.krakow.pl/2012/02/22/sektorkultury-ujecie-instytucjonalne-i-znaczenie-gospodarcze/ [dostęp 10.04.2018].

Słaby T., Rynek pracy w kulturze 1998-2002, Instytut im. Adama Mickiewicza, Warszawa 2005.

Stano-Strzałkowska S., Finansowanie kultury ze środków publicznych przykłady krajów europejskich, Warszawa 2017, http://konferencjakultury.pl/_admin/ stuff/okk_finansowanie-_kultury_1.pdf [dostęp 10.04.2018].

Throsby D., Ekonomia i kultura, Narodowe Centrum Kultury, Warszawa 2010.

Wąsowska-Pawlik A. (2013), Polityka kulturalna Polski 1989-2012, [w:] J. Hausner, A. Karwińska, J. Purchla (red.), Kultura a rozwój, Narodowe Centrum Kultury, Warszawa 2013, s. 107-125.

\title{
The culture sector in Poland - a local approach
}

\begin{abstract}
The cultural sector, although it is not the largest sector of economic activity, has a significant impact on the economic development of the country. Both the state, as the main patron of culture, as well as the private sector together with the non-profit sector, support both the activities of the cultural sector and the creative industries sector. This article will address topics related to the development of the cultural sector in Poland, its main tasks and problems, elements of the cultural policy of the Polish state and the problems of globalization of culture. In addition, the following aspects will be discussed: the role, objectives and forms of financing the cultural sector in Poland, analysis of the current situation of artists and creators on the Polish market, employment structure in the cultural sector, and problems and threats to cultural activities in Poland.
\end{abstract}

Keywords: culture sector, cultural policy, artists, employment, globalization. 